\title{
Milking Cows Once Daily Influences Behavior and Udder Firmness at Peak and Mid Lactation
}

\author{
C. B. Tucker, ${ }^{\star 1}$ D. E. Dalley, $†$ J.-L. K. Burke, ${ }^{*}$ and D. A. Clark† \\ ${ }^{*}$ AgResearch Ltd., Hamilton, New Zealand \\ †Dexcel Ltd., Hamilton, New Zealand
}

\begin{abstract}
Our aim was to evaluate the effects of once-daily milking on the welfare of dairy cows in a pastoral-based farming system. There are concerns that cows milked only once daily may experience discomfort associated with udder distension. We evaluated the behavior, including lying time and postures, grazing patterns, and kicking behavior in the parlor, and measures of udder firmness in cows milked once daily in 2 experiments: 1 ) at peak lactation, comparing cows milked once $(1 \times)$ or twice-daily $(2 \times)$ from the time of calving ( $n=4$ groups; $1 \times$ and $2 \times$ treatments); and 2) during the transition from $2 \times$ to $1 \times$ milking at mid lactation ( $\mathrm{n}=12$ groups; $1 \times, 2 \times$, and $2 \times$ to $1 \times$ treatments or TRANS). At peak lactation, cows milked $1 \times$ were more likely to lie with their hind legs touching the body than cows milked $2 \times$. There were no differences in udder firmness ( $1 \times$ : 10.0 vs. $2 \times$ : $9.9 \pm 0.13 \mathrm{~g}$ of force) or kicking ( $1 \times: 25$ vs. $2 \times$ : $24 \pm 7.8 \%$ ) behavior in the parlor. In the second experiment, milking frequency was reduced from $2 \times$ to $1 \times$ and this change resulted in an increase in udder firmness (1×: 9.1, $2 \times$ : 9.3, and TRANS: $9.5 \pm 0.14 \mathrm{~g}$ of force). Despite these differences in udder firmness, lying time ( $1 \times: 10.1,2 \times: 9.5$, and TRANS: $9.6 \pm 0.38 \mathrm{~h} / 24 \mathrm{~h}$ ), postures, and concentrations of fecal glucocorticoid metabolites (1×: 10.0, 2×: 10.5, and TRANS: $10.4 \pm 0.49 \mathrm{ng} / \mathrm{g}$ of feces in the $3 \mathrm{~d}$ after transition) in cows milked $1 \times$ or $2 \times$ were similar. Although milking frequency did not influence total time spent grazing, the diurnal grazing pattern of cows milked $2 \times$ was disrupted by afternoon milking at both peak and mid lactation. Cows milked $2 \times$ were able to compensate for this by grazing more after the return to pasture (DIM 153 to $155,1 \times$ : 52 vs. $2 \times: 66 \pm 6.2 \mathrm{~min} / 90 \mathrm{~min}$ of grazing). Cows milked $1 \times$ had slightly longer strides than $2 \times$ cows at mid lactation (1×: $0.73,2 \times: 0.70$, and TRANS: $0.70 \pm 0.014$ strides/ $\mathrm{m})$. In conclusion, under our experimental conditions,
\end{abstract}

Received September 6, 2006.

Accepted December 7, 2006.

${ }^{1}$ Corresponding author: cbtucker@ucdavis.edu we found no overt changes in behavior or physiology to indicate that the welfare of cows milked $1 \times$ is impaired. Key words: behavior, cortisol, milking frequency, udder firmness

\section{INTRODUCTION}

Decisions about milking frequency are often influenced by the milk price:input cost ratio of the farming system. For many dairy farmers, milking cows twice daily $(\mathbf{2} \times)$ is the accepted norm. In pasture-based systems with low milk prices, however, the cost and accessibility of labor, as well as lifestyle choices, influence the decision about milking frequency. In New Zealand, a growing number of farmers are choosing to incorporate once-daily milking $(\mathbf{1} \times)$ into their management system in 1 of 2 ways. Farmers opt to milk $1 \times$ for the entire lactation from calving onwards or, more commonly, to milk $2 \times$ through the start of the lactation and switch to $1 \times$ during mid lactation (Davis et al., 1999).

From the perspective of the cow, milking $1 \times$ has several advantages. Cows milked $1 \times$ produce less milk (Davis et al., 1999) and, therefore, may have reduced risk of metabolic disorders (Rauw et al., 1998). Milking $1 \times$ likely reduces interactions with handlers that cattle find aversive, such as shouting (Pajor et al., 2003), or that may increase risk of lameness, such as rough handling when moving cows into the parlor (Chesterton et al., 1989). Total daily walking distances in pasturebased dairy farms can be reduced by milking $1 \times$. In New Zealand, the average farm size is increasing (Livestock Improvement Corp., 2004) and milking $1 \times$ is a strategy for utilizing pasture further from the milking parlor without forcing animals to walk distances beyond the current average of $1.9 \mathrm{~km}$ 1-way (Tucker et al., 2005). In addition, milking cows $1 \times$ reduces the maximum body temperature and heat stress associated with walking to the milking parlor during summer weather $(\mathrm{P}$. Kendall, Ag Research Ltd., Hamilton, New Zealand; personal communication).

There are concerns that cows milked only $1 \times$, or with reduced milking frequency, may experience discomfort associated with udder distension and inflammatory re- 
sponse (Davis et al., 1998b), particularly in the later stages of milk accumulation. Indeed, cows may prefer to be milked more often than $1 \times$. When kept with the calf, cows will be suckled 4 times in a 24 -h period (Lidfors and Jensen, 1988) and dairy cows grazed at pasture will visit a robotic milking station 2.3 times in a 24 -h period (Ketelaar et al., 1999). There is limited evidence from other systems that missed milkings or reduced milking frequency may cause discomfort. In robotic milking systems, cows that miss a milking due to mechanical failure spend less time lying down in the hour following the omitted milking than animals without a missed milking (Stefanowska et al., 2000). In addition, cows milked $2 \times$ had shorter lying bouts than animals milked thrice daily, and this difference may be due to discomfort associated with udder distension (Österman and Redbo, 2001). Research into the possible discomfort associated with milking cows $1 \times$ from calving or during the transition to $1 \times$ at mid lactation is required. Indeed, the effects of reduced milking frequency are relevant to systems with low milk prices, but also to other systems such as automatic milking systems (due to missed milkings) and during the dry-off period in many dairy systems where $1 \times$ milking is used to further reduce milk yield prior to drying off.

If milking $1 \times$ caused discomfort, we predicted that cows would spend less time lying down, be more likely to lie in positions that reduced pressure on the udder, take shorter strides when walking, have firmer udders, be more likely to leak milk and kick in the parlor, and have increased hypothalamic-pituitary-adrenal axis activity compared with cows milked $2 \times$. In addition, we predicted that cows milked $1 \times$ would spend less time grazing than cows milked $2 \times$ because of lower energy requirements. We predicted that these differences would be apparent at peak lactation and during the transition from $2 \times$ to $1 \times$ milking at mid lactation.

In this experiment, our objective was to evaluate the effects of $1 \times$ milking on dairy cattle behavior and udder firmness in a pastoral-based farming system. Specifically, we aimed to 1) compare the effects of milking frequency ( $1 \times$ vs. $2 \times$ from calving) at peak and mid lactation on behavior and udder firmness; and 2) compare the effects of the transition from $2 \times$ to $1 \times$ milking at mid lactation on the behavior, udder firmness, and hypothalamic-pituitary-adrenal axis activity of dairy cows.

\section{MATERIALS AND METHODS}

\section{Peak Lactation $(D I M=52)$}

Cows and Treatments. Forty Friesian cows were studied in September 2005, in Hawera, New Zealand. Cows were milked either $1 \times$ or $2 \times$ from the time of calving. At the start of our experiment, cows averaged $( \pm$ SD) $5.5 \pm 2.5 \mathrm{yr}$ of age, $52 \pm 11 \mathrm{DIM}$, weighed $510 \pm$ $61 \mathrm{~kg}$, and produced $27.3 \pm 4.5 \mathrm{~kg} / \mathrm{d}$ of milk (1×: $24.5 \pm$ $4.7 \mathrm{~kg} / \mathrm{d}, 2 \times: 28.1 \pm 5.1 \mathrm{~kg} / \mathrm{d})$. Parity was $4.5 \pm 2.5$. Morning milking took place between 0700 and $0830 \mathrm{~h}$ and afternoon milking took place from 1530 to $1700 \mathrm{~h}$; cows milked $1 \times$ were milked in the morning. Cows were maintained on perennial ryegrass-white clover pasture with an average pasture cover of $3,375 \mathrm{~kg}$ of DM/ha and fresh pasture was provided every $24 \mathrm{~h}$ after the morning milking. Three days before the start of behavioral observations, cows were split into 4 groups of 10 cows/group ( 2 groups milked $1 \times, 2$ groups milked $2 \times$ ), balanced by milk production within milking frequency treatment. All cows had access to fresh water in their grazing area.

Behavioral Observations. Dairy cattle behavior was monitored at pasture and in the milking parlor. The behavior of the cows at pasture was recorded for 3 consecutive 24-h periods (DIM 52 to 55). One observer recorded the behavior of all cows in a single group with instantaneous scan sampling every $10 \mathrm{~min}$. We recorded the time spent grazing, standing without grazing, and lying. In addition, when the cows were lying we recorded the position of their legs and if the cows were lying with their weight on their side (Table 1). Individual cows were identified with collars and unique symbols on their side painted with animal markers (Tell tail paint, Fil NZ Ltd., Mount Maunganui, New Zealand). Multiple observers were used to collect the behavioral information at pasture. Interobserver reliability, as measured by percentage agreement, was between 90 and $100 \%$ for all behaviors. Interobserver agreement was lowest when assessing if the exposed hind leg was bent (90\% agreement).

During $4 \mathrm{~d}$ (DIM 53 to 57) cow behavior was recorded in the milking parlor during the morning milking. As cows entered the parlor, the number of steps (hind leg lifted off the ground in an upward motion) and kicks (hind leg lifted off the ground in an outward motion, toward the handler or underside of cow) performed in the time required for complete attachment of the milking apparatus was recorded. The observer stopped counting the number of steps and kicks when the handler moved onto the next cow. A single observer was used to collect this information.

Measurements of Udder Firmness and Stride Length. Upon entry into the milking parlor (a.m. milking on DIM 52 to 57), milk leaking from teats was recorded. We measured udder firmness by pressing a steel rod (10-mm diameter) against a marked spot in the middle of the rear left quarter of the mammary gland. The steel rod was attached to a spring and provided an estimate of the grams of force required to 
Table 1. Definitions of behaviors used to evaluate the effects of milking cows once or twice daily in pastoral farming system

\begin{tabular}{ll}
\hline Behavior & \multicolumn{1}{c}{ Definition } \\
\hline Grazing & $\begin{array}{l}\text { Grass was ingested or head moved side to side, with mouth/nose in contact with grass } \\
\text { Standing, not grazing }\end{array}$ \\
$\begin{array}{l}\text { Lying } \\
\text { Positions while lying: }\end{array}$ & Flank was in contact with ground \\
Lying with weight on lateral side & Weight placed on side of the body \\
Underside front leg, bent & Underside leg bent at knee and hoof pointed back toward body \\
Exposed front leg, bent & Exposed leg bent at knee and hoof pointed back toward body \\
Exposed hind leg, bent & Exposed hind leg bent at less than $90^{\circ}$ angle \\
Exposed front leg, touching & When leg is tucked, there is no visible gap between the metacarpus and fetlock joint \\
Exposed hind leg, touching & Exposed hind leg (metatarsus) touched the trunk or udder \\
\hline
\end{tabular}

bring $5 \mathrm{~cm}$ of the steel rod flush with the surrounding Plexiglas plate (radius $5 \mathrm{~cm}$ ). This device measured a range of force from 0 to $13 \mathrm{~g}$.

Stride length was recorded before and after the a.m. milking on DIM 52 to 57 . A video camera was used to record each cow and the stride length as each cow walked, single file, along a 15-m length of farm laneway. Stride length was calculated from the number of steps taken by the hind legs to traverse the $15-\mathrm{m}$ distance. The laneway surface was fine, sandy gravel.

Statistical Analysis. The group (mean values for 10 cows in each group) served as the experimental unit for all analyses $(n=4)$. All dependent variables were analyzed with a repeated-measure ANOVA in SAS (SAS Institute, 1999). The model tested the overall effect of treatment (milked $1 \times$ vs. $2 \times ; 1 \mathrm{df}$ ) against an error term $(2 \mathrm{df})$. The time by treatment interaction (Greenhouse-Geisser) was never significant and is not reported.

\section{Transition from 2× to $1 \times$ at Mid Lactation $(D I M=153,156)$}

Cows and Treatments. Sixty Friesian cows were studied in January 2006, in Hawera, New Zealand. Cows were milked either $1 \times(n=20)$ or $2 \times(n=40)$ daily from the time of calving. Cows were split into 12 separate groups of 5 cows/group $3 \mathrm{~d}$ before observations began (DIM = 150). Groups were balanced for milk production and assigned to 1 of 3 treatments: milked $1 \times$ (from the time of calving); milked $2 \times$ (from the time of calving); and milked $2 \times$ from calving and for the first $3 \mathrm{~d}$ of the experiment (approximately DIM 153 to 156) and then switched to $1 \times$ (TRANS; on the afternoon of DIM 156). Morning milking took place between 0600 to $0830 \mathrm{~h}$ and afternoon milking took place from 1530 to $1630 \mathrm{~h}$. Cows milked $1 \times$ were milked in the morning. At the start of our experiment, cows were $5.1 \pm 2.6$ $( \pm \mathrm{SD}) \mathrm{yr}$ of age, $153 \pm 21 \mathrm{DIM}$, weighed $514 \pm 54 \mathrm{~kg}$, and produced $16.5 \pm 4.1 \mathrm{~kg} / \mathrm{d}$ milk $(1 \times: 15.0 \pm 3.3 \mathrm{~kg} / \mathrm{d}$, $2 \times: 16.7 \pm 4.4 \mathrm{~kg} / \mathrm{d}$, TRANS: $17.9 \pm 4.1 \mathrm{~kg} / \mathrm{d})$. Parity was
$4.1 \pm 2.6$. Cows were maintained on perennial ryegrasswhite clover pasture with an average pasture cover of $3,317 \mathrm{~kg}$ of $\mathrm{DM} / \mathrm{ha}$, and fresh pasture was provided every $24 \mathrm{~h}$ after the morning milking. All cows had visual and auditory contact with animals in the other 2 treatments and had access to fresh water in their grazing area.

Behavioral Observations. The behavior of the cows was recorded $24 \mathrm{~h} / \mathrm{d}$ at pasture during the $3 \mathrm{~d}$ before (DIM 153 to 155) and the $7 \mathrm{~d}$ after (DIM 156 to 163) the transition from milking $2 \times$ to $1 \times$. One observer recorded the behavior of all cows in a single group with instantaneous scan sampling every $10 \mathrm{~min}$. Time spent grazing, standing without grazing, lying position, and leg position were recorded as described previously. Interobserver reliability was between 94 and 100\% for all behaviors. Interobserver agreement was lowest when assessing if the exposed hind leg was bent (94\% agreement).

Data loggers (Tiny-Tag, Gemini Dataloggers Ltd., Chichester, UK) were used to measure the number of lying bouts and the duration of each lying bout for 1 cow in each group $(n=12)$. The loggers were attached to the outer side of the hind legs (metatarsus) of the cows using multiple layers of wrap below, above, and around the device and were set to record position every $1 \mathrm{~min}$. Halfway through the experiment the loggers were switched to the opposite hind leg to minimize the chance of hair loss.

The vocal response and time spent standing near the gate during the afternoon milking was recorded on DIM 156 to 160 to assess the response to the change in milking routine. The groups that were not milked during this time ( $1 \times$ and TRANS treatments) were observed. Observations began when the gate for the cows milked $2 \times$ was opened and ended in the 5 -min period after cows milked in the afternoon returned. The number of calls per group was continuously recorded during 5-min intervals $(65 \pm 9 \mathrm{~min})$. In addition, the number of cows standing with at least the front hooves within approximately $36 \mathrm{~m}^{2}(6 \mathrm{~m} \times 6 \mathrm{~m}$ square $)$ of the entrance to the 
Table 2. Behavioral responses (mean \pm SEM) of cows milked either once $(1 \times)$ or twice $(2 \times)$ daily during peak lactation (52 DIM) in a pastoral farming system

\begin{tabular}{|c|c|c|c|c|}
\hline Behavior & \multicolumn{2}{|c|}{ Milking frequency ${ }^{1}$} & SEM & $P$ \\
\hline Grazing $(\mathrm{h} / 24 \mathrm{~h})$ & 8.3 & 9.0 & 0.43 & 0.122 \\
\hline Lying $(\mathrm{h} / 24 \mathrm{~h})$ & 9.8 & 8.3 & 0.56 & 0.064 \\
\hline \multicolumn{5}{|l|}{ Positions while lying: } \\
\hline Lying with weight on lateral (\% of lying time) & 2 & 2 & 0.5 & 0.909 \\
\hline Underside front leg, bent (\% of lying time) & 82 & 84 & 2.7 & 0.680 \\
\hline Exposed front leg, touching (\% of lying time) & 40 & 41 & 3.7 & 0.315 \\
\hline Exposed hind leg, touching (\% of lying time) & 29 & 21 & 3.1 & 0.052 \\
\hline Neither front or hind leg touching (\% of lying time) & 49 & 53 & 4.0 & 0.312 \\
\hline Combination of both front legs tucked and hind leg touching the body ( $\%$ of lying time) & 26 & 20 & 2.5 & 0.059 \\
\hline
\end{tabular}

${ }^{1}$ Cows were milked $1 \times$ or $2 \times$ from calving (average of $3 \mathrm{~d}$ of observation).

paddock was counted with instantaneous scan sampling every 5 min.

Measurements of Udder Firmness and Stride Length. During the $3 \mathrm{~d}$ before (DIM 153 to 155) and the $7 \mathrm{~d}$ after the transition to milking $1 \times$ (a.m. milking on DIM 156 to 164), we recorded if milk was leaking from the teats upon entry into the parlor. Udder firmness was measured as described previously. Infrared temperatures of the udder were recorded at a distance of $0.5 \mathrm{~m}$ using a ThermaCam S60 (FLIR Systems AB, Danderyd, Sweden) before a.m. milking on DIM 156 to 159 . The average temperature of each udder was calculated by tracing the area of the mammary gland using ThermaCAM Researcher Pro 2.7 software (FLIR Systems AB).

Stride length was recorded before and after the a.m. milking on DIM 154 to 164 as previously described.

Fecal Glucocorticoid Metabolites. Fecal samples were collected by rectal palpation the morning of the transition (DIM 156) and on the $3 \mathrm{~d}$ after the transition to milking $1 \times$ (DIM 157 to 159 ) before morning milking. The samples were immediately placed on ice and stored at $-18^{\circ} \mathrm{C}$ until extraction and analysis. Fecal glucocorticoid metabolite concentrations were measured in duplicate using a commercially available RIA kit (Rats \& Mice Corticosterone kit; ICN Pharmaceuticals, Costa Mesa, CA) previously validated for cattle feces (Morrow et al., 2002). The antibody cross-reacts with corticosterone $100 \%$, desoxycorticosterone $0.34 \%$, testosterone $0.1 \%$, cortisol $0.05 \%$, aldosterone $0.03 \%$, and progesterone $0.02 \%$ (manufacturer's data). These results are expressed as glucocorticoid metabolite per gram of dry feces.

Statistical Analysis. All estimates of lying time and postures collected with observation are reported for both the 24-h period and for the 4-h period before morning milking because this was when expected milk accu- mulation was greatest. Grazing time was reported as the total time in $24 \mathrm{~h}$ and 90 min after the cows milked $2 \times$ returned from afternoon milking.

The group served as the experimental unit for all analyses $(n=12)$. When measurements were taken for multiple cows within a group, the group mean was used. All dependent variables were analyzed with a repeatedmeasure ANOVA in SAS (SAS Institute, 1999). The model tested the overall effect of treatment ( $2 \mathrm{df}$ ) against an error term $(9 \mathrm{df})$. The probability reported for the time by treatment interaction was the GreenhouseGeisser value.

\section{RESULTS}

\section{Peak Lactation}

Behavioral Observations. Cows milked $1 \times$ spent $9.8 \mathrm{~h} / \mathrm{d}$ lying down, whereas cows milked $2 \times$ spent 8.3 $\mathrm{h} / \mathrm{d}$ lying down $( \pm 0.56 \mathrm{SEM}, P=0.064$, Table 2$)$. Cows milked $1 \times$ spent $29 \%$ of the time lying with their hind legs touching their body or udder $(P=0.052)$, whereas cows milked $2 \times$ spent $21 \%$ in the same position $( \pm 3.1 \%)$. There were no differences in lying time or lying postures in the $4 \mathrm{~h}$ before morning milking $(P \geq 0.275$; data not presented).

Although there were no differences in the total time spent grazing or standing without grazing associated with milking frequency, the time cows spent grazing varied over the course of the day with peaks occurring both early in the morning and in the middle of the day (Figure 1). The afternoon grazing peak began around the same time that the cows milked $2 \times$ were taken to the milking parlor. Cows milked $2 \times$ compensated for the interruption in the grazing pattern by spending more time eating when they were returned to the pasture after milking. In the $90 \mathrm{~min}$ after the $2 \times$ cows returned from the afternoon milking, they were more 


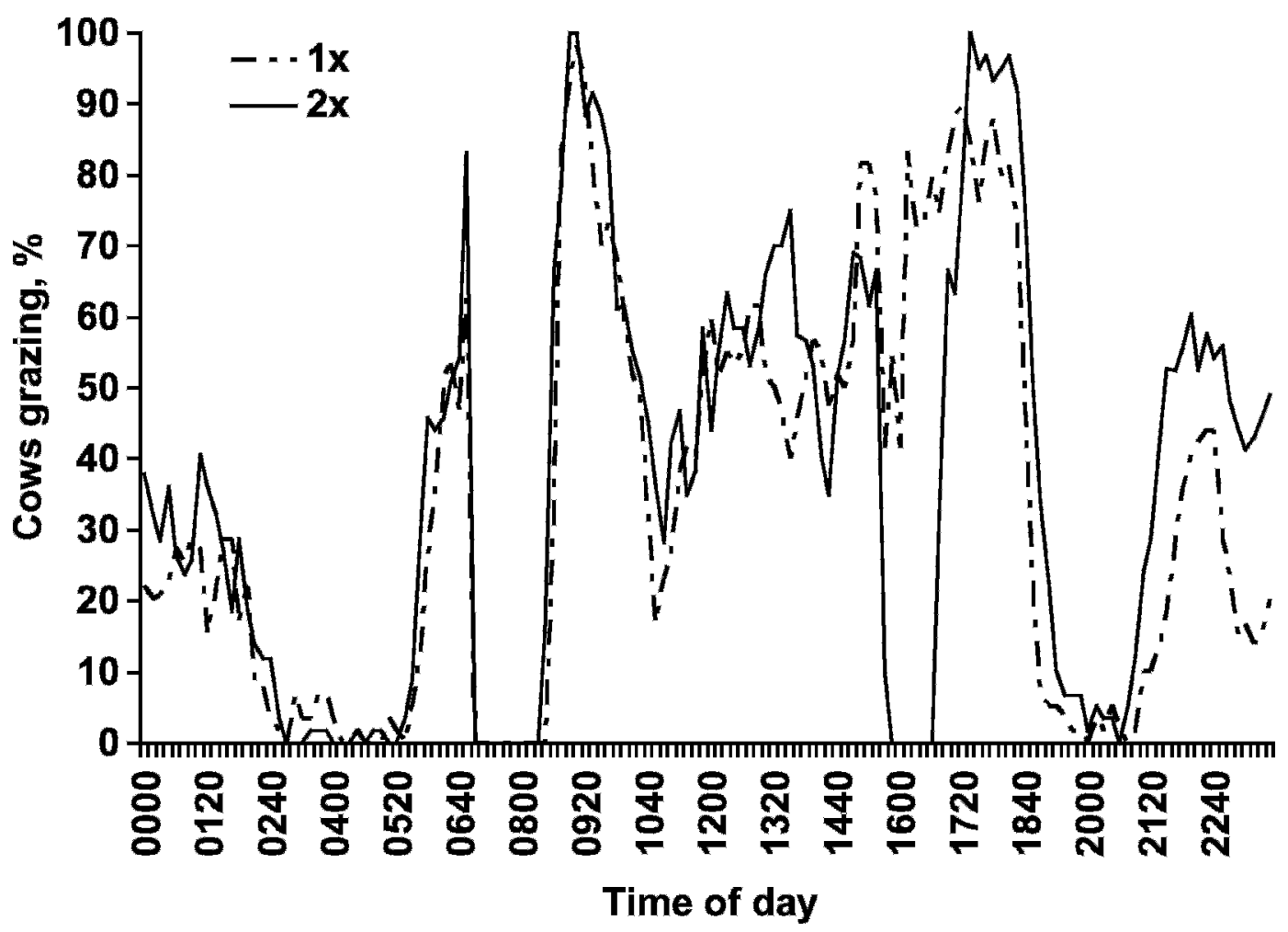

Figure 1. Percentage of cows grazing over a 24 -h period. Cows were milked either once $(1 \times)$ or twice $(2 \times)$ daily during peak lactation (DIM 52) in a pastoral farming system. Treatments were applied from calving onwards. Means (of $3 \mathrm{~d}$ of observation) are presented for the effect of milking frequency $(1 \times$ vs. $2 \times)$.

likely to spend time grazing than cows milked $1 \times(1 \times$ : $72 / 90$ min vs. $2 \times: 86 / 90 \mathrm{~min}$; SEM: $1.5 / 90 \mathrm{~min} ; P=0.051$; Figure 1).

Cows were equally likely to kick or step at least once while the milking apparatus was attached if they were milked $1 \times$ or $2 \times$ (kick: $1 \times: 25 \%$ vs. $2 \times$ : $24 \%$; SEM: $7.8 \%$, $P=0.699$, step: $1 \times: 68 \%$ vs. $2 \times: 61 \%$; SEM: $9.5 \%$ of cows, $P=0.588)$

Measurements of Udder Firmness and Stride Length. There were no differences in the incidence of milk leakage or udder firmness between the cows milked $1 \times$ or $2 \times$ (milk leakage: $1 \times: 31 \%$ vs. $2 \times$ : $21 \%$; SEM: $7.7 \% ; P=0.229$; udder firmness: $1 \times: 10.0 \mathrm{~g}$ of force vs. $2 \times: 9.9 \mathrm{~g}$ of force; SEM: $0.13 \mathrm{~g} ; P=0.590$ ). There were no differences in stride length between cows milked $1 \times$ or $2 \times$ either to or from the milking parlor at a.m. milking (Table 3).

\section{Transition from $2 \times$ to $1 \times$ Milking at Mid Lactation}

Behavioral Observations. There were no differences in total time spent lying, standing without grazing, or grazing associated with milking frequency at mid lactation (Table 4). There were no differences in lying times or postures during the $7 \mathrm{~d}$ following the transition to $1 \times$ milking from $2 \times$ milking (24-h means, Table 5). Indeed, there were no differences in lying time or postures in the $4 \mathrm{~h}$ before morning milking at any time ( $P \geq 0.341$; data not presented). There was no difference in the average length of lying bouts between treatments ( $1 \times: 71 \mathrm{~min} /$ bout, $2 \times: 76 \mathrm{~min} /$ bout, TRANS: $73 \mathrm{~min} /$ bout; SEM: $1.0 \mathrm{~min} / \mathrm{bout} ; P=0.954)$. After the transition, the cows milked $1 \times$ had more lying bouts than either the cows milked $2 \times$ or those that had undergone the transition to $1 \times$ milking $(1 \times: 9.3$ bouts $/ 24 \mathrm{~h}$, $2 \times: 7.0$ bouts/ $24 \mathrm{~h}$, TRANS: 7.7 bouts/24 h; SEM: 1.01 bouts/24 h; $P=0.018$ ).

Although there were no differences in the total time spent grazing or standing without grazing associated with milking frequency, the time cows spent grazing varied over the course of the day with peaks occurring both early in the morning and in the middle of the day (Figure 2). The afternoon grazing peak began around the same time the cows milked $2 \times$ were taken to the milking parlor. Cows milked $2 \times$ compensated for the interruption in grazing by spending more time grazing when they were returned to the pasture after milking. In the 90 min after the cows returned from the 
Table 3. Stride length of cows (mean \pm SEM) milked either once $(1 \times)$ or twice $(2 \times)$ daily during either peak (52 DIM) or mid lactation (153 DIM, 156 DIM) in a pastoral farming system ${ }^{1}$

\begin{tabular}{lccccc}
\hline & \multicolumn{3}{c}{ Milking frequency } & & \\
\cline { 2 - 4 } Stride length & $1 \times$ & $2 \times$ & TRANS & SEM & $P$ \\
\hline $\begin{array}{l}\text { Peak lactation } \\
\text { To parlor (strides/m) }\end{array}$ & 0.77 & 0.76 & - & 0.013 & 0.356 \\
$\quad$ From parlor (strides/m) & 0.77 & 0.77 & - & 0.021 & 0.946 \\
Mid lactation, before transition & & & & & \\
$\quad$ To parlor (strides/m) & 0.71 & 0.68 & 0.67 & 0.012 & 0.079 \\
$\quad$ From parlor (strides/m) & 0.74 & 0.72 & 0.71 & 0.018 & 0.425 \\
$\quad$ Mid lactation, after transition & & & & & \\
$\quad$ To parlor (strides/m) & 0.73 & 0.72 & 0.71 & 0.021 & 0.380 \\
$\quad$ From parlor (strides/m) & 0.73 & 0.70 & 0.70 & 0.014 & 0.009 \\
\hline
\end{tabular}

${ }^{1}$ Half of the cows milked $2 \times$ were switched to $1 \times$ milking (TRANS) at mid lactation. The values under "TRANS" represent either the $2 \mathrm{~d}$ before the transition (before transition, DIM 154 to 156) or the $6 \mathrm{~d}$ after the transition (after transition, DIM 157 to 163 ) of the TRANS group from $2 \times$ to $1 \times$ milking.

Table 4. Behavioral responses (means \pm SEM; average of $3 \mathrm{~d}$ of observation) of cows milked either once (1×) or twice (2×, TRANS) daily during mid lactation (153 DIM) in a pastoral farming system ${ }^{1}$

\begin{tabular}{|c|c|c|c|c|c|}
\hline \multirow[b]{2}{*}{ Behavior } & \multicolumn{3}{|c|}{ Milking frequency } & \multirow[b]{2}{*}{ SEM } & \multirow[b]{2}{*}{$P$} \\
\hline & $1 \times$ & $2 \times$ & TRANS $^{2}$ & & \\
\hline Grazing (h/24 h) & 8.1 & 7.9 & 7.8 & 0.36 & 0.789 \\
\hline Lying $(\mathrm{h} / 24 \mathrm{~h})$ & 9.6 & 9.3 & 9.3 & 0.27 & 0.526 \\
\hline \multicolumn{6}{|l|}{ Positions while lying: } \\
\hline Lying with weight on lateral (\% of lying time) & 1 & 1 & 1 & 0.5 & 0.944 \\
\hline Underside front leg, bent ( $\%$ of lying time) & 85 & 84 & 83 & 2.6 & 0.691 \\
\hline Exposed front leg, touching (\% of lying time) & 23 & 24 & 24 & 4.2 & 0.996 \\
\hline Exposed hind leg, touching (\% of lying time) & 14 & 11 & 14 & 2.6 & 0.502 \\
\hline Neither front or hind leg touching (\% of lying time) & 68 & 69 & 68 & 4.2 & 0.938 \\
\hline Combination of both front legs tucked and hind leg touching the body ( $\%$ of lying time) & 13 & 11 & 13 & 2.4 & 0.425 \\
\hline
\end{tabular}

${ }^{1}$ Values represent the $3 \mathrm{~d}$ before the transition from $2 \times$ to $1 \times$ milking (DIM 153 to 155 ).

${ }^{2}$ Cows were milked $2 \times$ from calving and then switched to $1 \times$ at mid lactation.

Table 5. Behavioral responses (means \pm SEM; of $7 \mathrm{~d}$ of observation, DIM 156 to 163 ) of cows milked either once (1×, TRANS) or twice (2×) daily during mid lactation (156 DIM) in a pastoral farming system ${ }^{1}$

\begin{tabular}{|c|c|c|c|c|c|c|}
\hline \multirow[b]{3}{*}{ Behavior } & & & & \multirow[b]{3}{*}{ SEM } & \multicolumn{2}{|c|}{$P$} \\
\hline & \multicolumn{3}{|c|}{ Milking frequency } & & \multirow{2}{*}{$\begin{array}{l}\text { Milking } \\
\text { frequency }\end{array}$} & \multirow{2}{*}{$\begin{array}{c}\text { Day } \times \\
\text { milking } \\
\text { frequency }\end{array}$} \\
\hline & $1 \times$ & $2 \times$ & TRANS $^{2}$ & & & \\
\hline Grazing (h/24 h) & 8.4 & 8.6 & 8.8 & 0.36 & 0.396 & 0.718 \\
\hline Standing, not grazing (h/24 h) & 5.5 & 5.8 & 5.6 & 0.54 & 0.753 & 0.694 \\
\hline Lying $(\mathrm{h} / 24 \mathrm{~h})$ & 10.1 & 9.5 & 9.6 & 0.38 & 0.403 & 0.192 \\
\hline \multicolumn{7}{|l|}{ Positions while lying: } \\
\hline Exposed front leg, bent (\% of lying time) & 98 & 99 & 99 & 0.4 & 0.058 & 0.673 \\
\hline Exposed hind leg, bent (\% of lying time) & 53 & 55 & 52 & 5.0 & 0.911 & 0.459 \\
\hline Exposed front leg, touching (\% of lying time) & 32 & 29 & 28 & 6.0 & 0.850 & 0.674 \\
\hline Exposed hind leg, touching (\% of lying time) & 18 & 15 & 18 & 2.8 & 0.644 & 0.898 \\
\hline Neither front or hind leg touching ( $\%$ of lying time) & 60 & 64 & 62 & 6.0 & 0.827 & 0.860 \\
\hline $\begin{array}{l}\text { Combination of both front legs tucked and hind leg touching } \\
\text { the body (\% of lying time) }\end{array}$ & 17 & 14 & 17 & 2.7 & 0.612 & 0.893 \\
\hline
\end{tabular}

${ }^{1}$ Values represent the first $7 \mathrm{~d}$ after the transition from $2 \times$ to $1 \times$ milking.

${ }^{2}$ Cows were milked $2 \times$ from calving and then switched to $1 \times$ at mid lactation. 


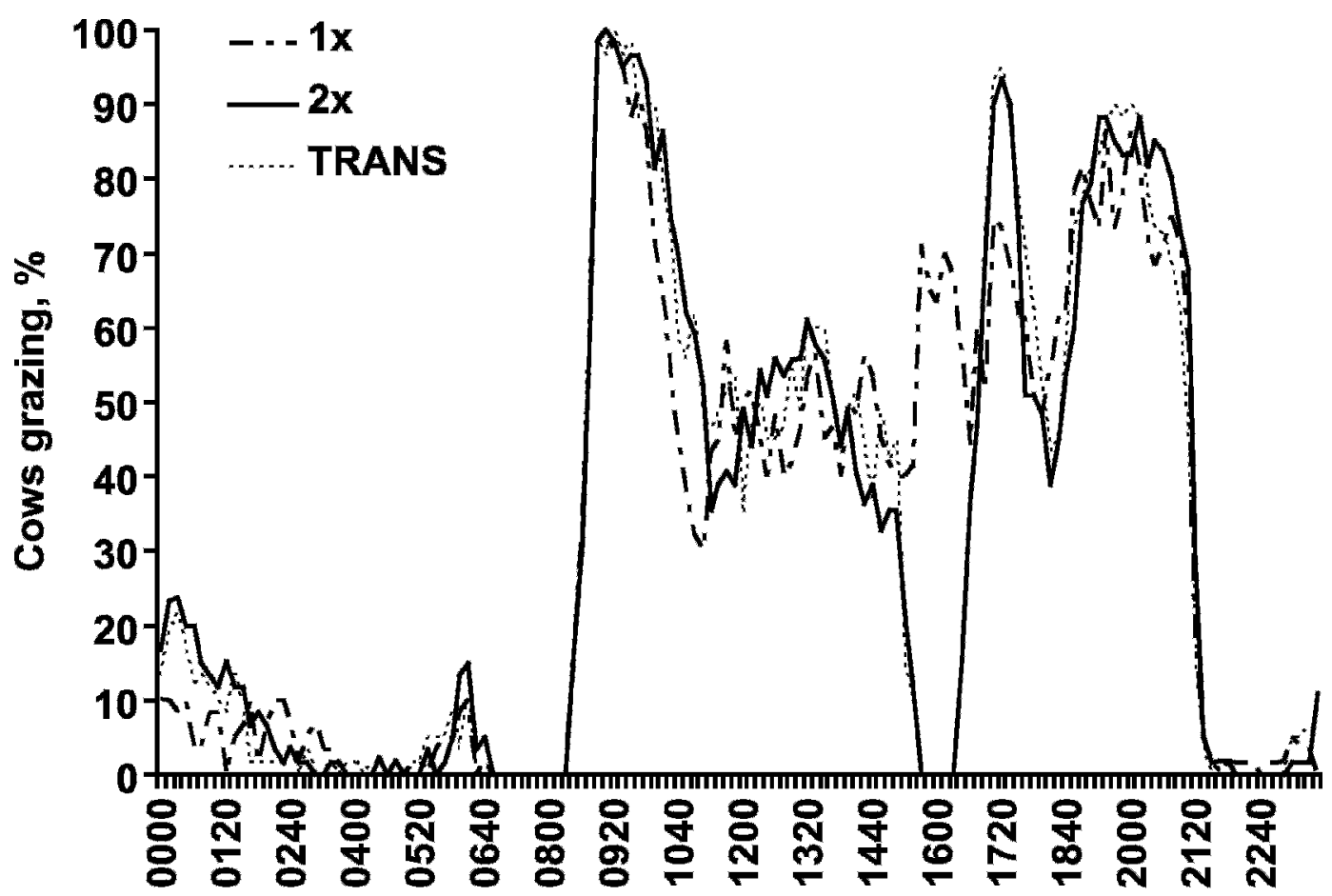

Time of day

Figure 2. Percentage of cows grazing over a 24 -h period when cows had been milked either once $(1 \times)$ or twice $(2 \times$, TRANS) daily during mid lactation (DIM 153) in a pastoral farming system. Cows were milked either $1 \times$ or $2 \times$ from the time of calving; half of the cows milked $2 \times$ were switched to $1 \times$ milking (TRANS). Means represent $3 \mathrm{~d}$ before the transition of the TRANS group from $2 \times$ to $1 \times$ milking (DIM 153 to 155$)$.

afternoon milking, cows milked $2 \times(2 \times$ and TRANS during DIM 153 to 155, Figure 2; and 2× in DIM 156 to 163 , Figure 3 ) were more likely to spend time grazing than cows milked only $1 \times$ (before the transition, DIM 153 to 155 , $1 \times$ : 52/90 min, $2 \times$ : 66/90 min, TRANS: 68/ 90 min; SEM: 6.2/90 min grazing; $P=0.04$, Figure 2). After the transition to being milked only $1 \times$, the cows in the TRANS treatment immediately switched their grazing pattern and spent less time eating (similar to $1 \times$ cows) during the 90 min after the cows milked $2 \times$ had returned to pasture (after the transition, DIM 156 to $163,1 \times$ : $48 / 90 \mathrm{~min}, 2 \times$ : 57/90 min, TRANS: $48 / 90$ min; SEM: 7.0/90 min grazing; $P=0.076$, Figure 3).

In addition to immediately switching their grazing pattern in response to being milked only $1 \times$, cows did not show a strong behavioral response to missing the afternoon milking. They spent little time standing at the gate; whereas the cows milked $2 \times$ were taken to the parlor in the afternoon (1×: $2.8 \%$, TRANS: $9.7 \%$; $\mathrm{SEM}=9.3 \%$ time at least $1 \mathrm{cow}$ stood at gate; $P=$ $0.236)$. In addition, cows did not vocalize during this 65-min period (1×: 0.02, TRANS: 0.03; SEM: 0.02 call/ $\min ; P=0.670)$.
Measurements of Udder Firmness and Stride Length. Before the change in milking frequency, both the incidence of milk leakage upon entry the parlor and udder firmness were similar between cows in the 3 treatment groups (Figures 4 and $5 ; P=0.950$ ). After the transition to $1 \times$ milking, the TRANS group was at least twice as likely to have milk leakage when entering the parlor (Figure $4 ; P<0.005$ ) and had firmer udders than cows milked $1 \times$ or $2 \times$ from the time of calving (Figure $5 ; P=0.024$ ). The cows undergoing the transition to $1 \times$ milking had the highest incidence of milk leakage and levels of udder firmness of all 3 treatments during the $7 \mathrm{~d}$ following the transition (interaction between time and treatment of milk leakage and udder firmness; $P \geq 0.145$ ); however, the difference between the transition treatment and the $1 \times$ and $2 \times$ milking treatments was greatest on the first day following the transition and declined over time. Cows milked $1 \times$ had longer strides from the parlor after transition (Table 3) than $2 \times$ and TRANS cows.

Before the transition to $1 \times$ milking, the cows milked $2 \times$ had warmer udders than cows milked $1 \times\left(1 \times: 32.1^{\circ} \mathrm{C}\right.$ vs. $2 \times: 32.9^{\circ} \mathrm{C}$; SEM: $0.26^{\circ} \mathrm{C} ; P=0.042$ ), although there 


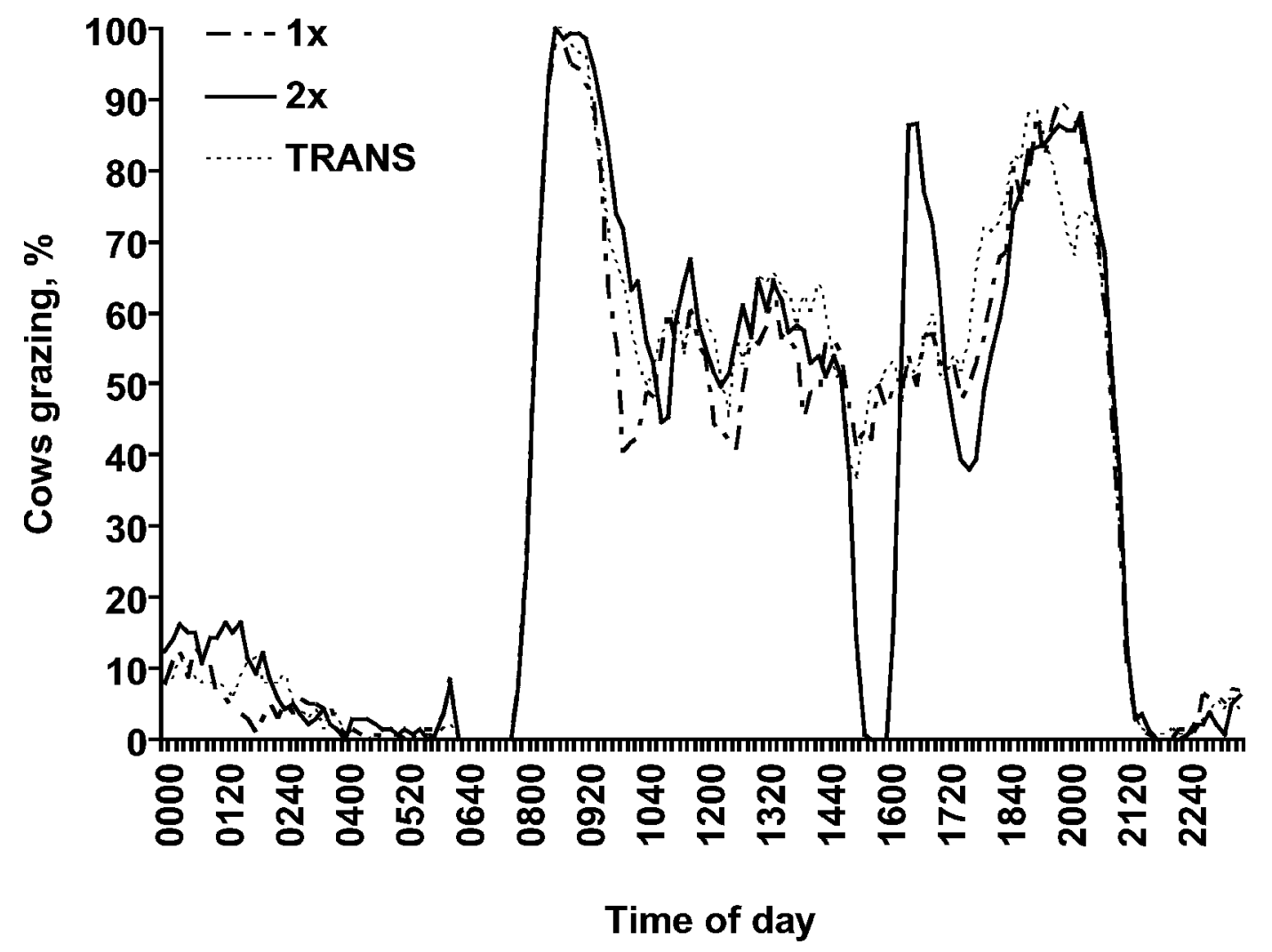

Figure 3. Percentage of cows grazing over a 24 -h period when cows had been milked either once (1×, TRANS) or twice $(2 \times)$ daily during mid lactation (DIM 156) in a pastoral farming system. Cows had been milked either $1 \times$ or $2 \times$ daily from the time of calving. Half of the cows milked $2 \times$ then switched to $1 \times$ milking (TRANS). Means represent the $7 \mathrm{~d}$ after the transition of the TRANS group from $2 \times$ to $1 \times$ daily milking (DIM 156 to 164).

was no difference between the cows in the transition treatment and the $1 \times$ and $2 \times$ milking treatments $(P \leq$ $0.204)$. After the transition to $1 \times$ milking, cows in the $2 \times$ milking treatment continued to have warmer udders compared with cows in either the $1 \times$ milking or transition treatment $\left(1 \times: 31.9^{\circ} \mathrm{C}, 2 \times: 33.1^{\circ} \mathrm{C}\right.$, TRANS: $32.0^{\circ} \mathrm{C}$; SEM: $\left.0.48^{\circ} \mathrm{C} ; P=0.047\right)$.

Fecal Glucocorticoid Metabolites. There were no differences in fecal glucocorticoid metabolite concentrations (ng/g of feces) the day before or in the $3 \mathrm{~d}$ after the transition to $1 \times$ milking ( $1 \mathrm{~d}$ before: $1 \times: 10.2 \mathrm{ng} / \mathrm{g}$, $2 \times$ : $11.6 \mathrm{ng} / \mathrm{g}$, TRANS: $11.6 \mathrm{ng} / \mathrm{g}$; SEM: $0.67 \mathrm{ng} / \mathrm{g} ; P=$ 0.344; average of $3 \mathrm{~d}$ after: $1 \times: 10.0 \mathrm{ng} / \mathrm{g}, 2 \times: 10.5 \mathrm{ng} /$ g, TRANS: $10.4 \mathrm{ng} / \mathrm{g}$; SEM: $0.49 \mathrm{ng} / \mathrm{g} ; P=0.606$ ).

\section{DISCUSSION}

Cows milked $1 \times$ reduced their grazing time by $8 \%$ at peak lactation and not at all in mid lactation compared with cows milked $2 \times$. This difference in grazing time at peak lactation was not statistically different; however, the direction of the difference is as expected given that cows milked $1 \times$ produced less milk, likely had lower energy requirements than cows milked $2 \times$ (Clark et al., 2006), and had lower feed intake (8\% difference at peak lactation, no difference between January and April; Holmes et al., 1992).

Although there were no significant differences in total time spent grazing, milking frequency influenced the grazing pattern. All cows began the afternoon grazing activity around the time of afternoon milking. When cows were milked $2 \times$, however, this grazing activity was interrupted when the animals were taken to the parlor. Cows milked $2 \times$ compensated for this interruption by more intense grazing activity when they returned to the pasture, although no new fresh pasture was provided at this time.

When milking frequency was reduced in mid lactation, cows undergoing this change immediately switched their grazing pattern to match those of the cows milked $1 \times$. Cows in both treatments could see and hear each other and social facilitation may have dampened the response to the missed milking, because the cows milked $1 \times$ were used to this routine. In other 


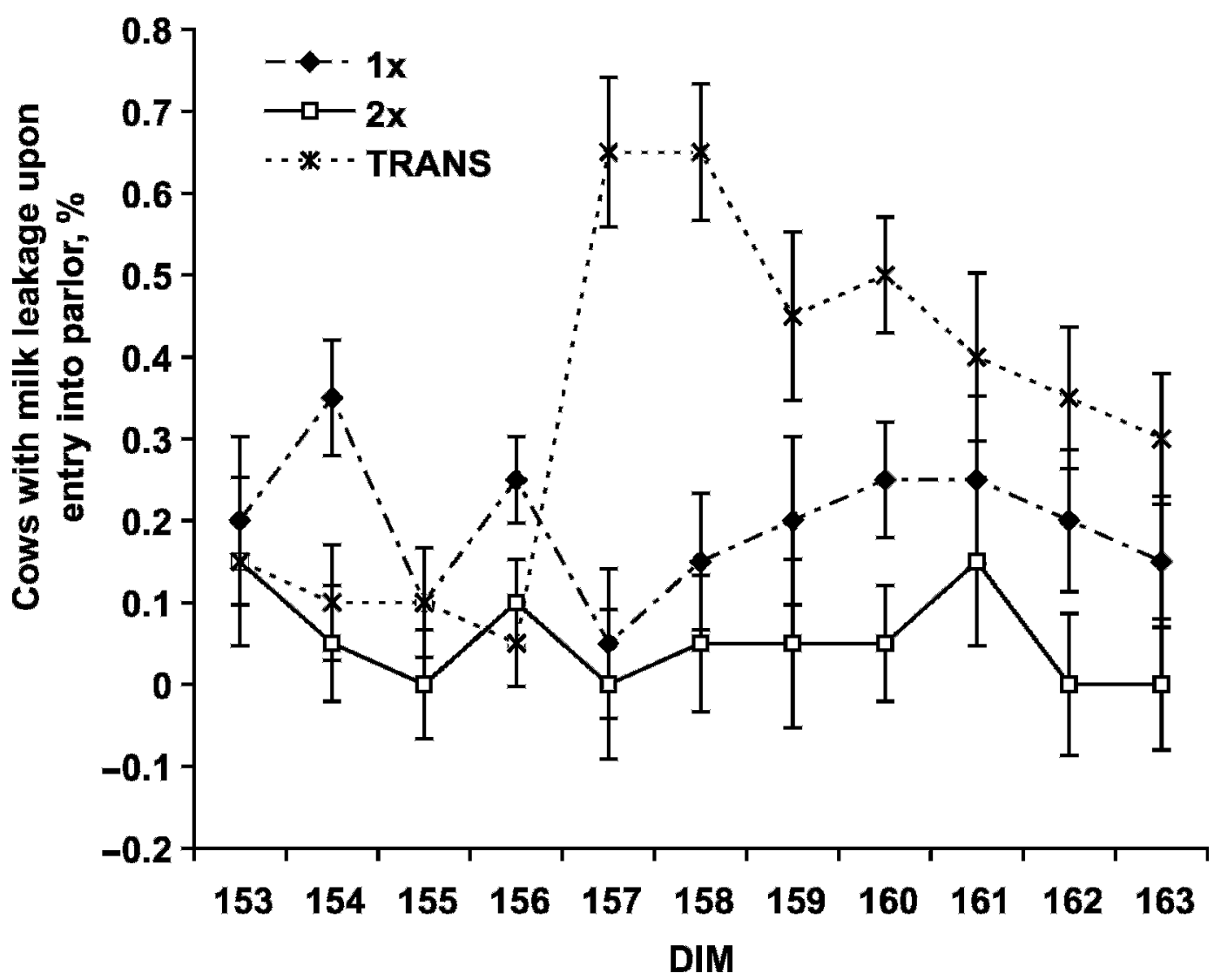

Figure 4. Percentage of cows with milk leakage upon entry into the milking parlor. Cows had been milked either once daily (1×), twice daily $(2 \times)$, or undergone the transition from $2 \times$ to $1 \times$ (TRANS) during mid lactation in a pastoral farming system. The TRANS group switched from $2 \times$ to $1 \times$ milking on the afternoon of DIM 156; thus, the first milking after the change was DIM 157. Bars represent SEM.

experiments, however, cows offered the choice between milking and a food reward in a Y-maze all choose to feed rather than be milked (Prescott et al., 1998); thus, it seems unlikely that social facilitation is the sole explanation for our results. When the cows in our experiment were allowed to stay at pasture, they continued to graze (Figures 1, 2, and 3), and there is limited evidence that remaining behind at pasture was stressful for them. Cows undergoing the transition from $2 \times$ to $1 \times$ milking were no more likely to stand at the gate waiting to leave the pasture and did not vocalize any more than cows milked $1 \times$ from calving. Cows with free access to an automatic milking machine choose to leave pasture; the majority of visits $(35 \%)$ to the robotic milker occurred in the afternoon (Ketelaar et al., 1999). Together, these results suggest that neither missing nor attending the afternoon milking is unduly stressful.

Cows milked $1 \times$ spent numerically more time lying down than their counterparts milked $2 \times$ during peak lactation. The difference in lying time at peak lactation $(1.5 \mathrm{~h})$ is only slightly more than the time associated with the afternoon milking. It is possible that the lower lying times are due to fewer time constraints associated with $1 \times$ milking. In contrast, previous studies reported reduced lying times associated with less frequent milking $(2 \times$ vs. $3 \times$ daily or omitted milking in automatic milking systems; Stefanowska et al., 2000; Österman and Redbo, 2001). Other authors have interpreted the decrease in lying time as a sign of discomfort associated with udder distension; however, we were unable to replicate these results, even in the $4 \mathrm{~h}$ before morning milking, when we would expect that milk accumulation, and therefore discomfort, would be greatest (Davis et al., 1998a).

We predicted that cows milked only $1 \times$ would be more likely to lie in positions that reduced pressure on the udder, namely with the hind leg away from the body, weight on the side of the body by using the front leg as a fulcrum, or by lying in a lateral position. We also predicted that cows experiencing discomfort associated with udder firmness would have shorter lying bouts to reduce pressure on the mammary gland (Österman and 


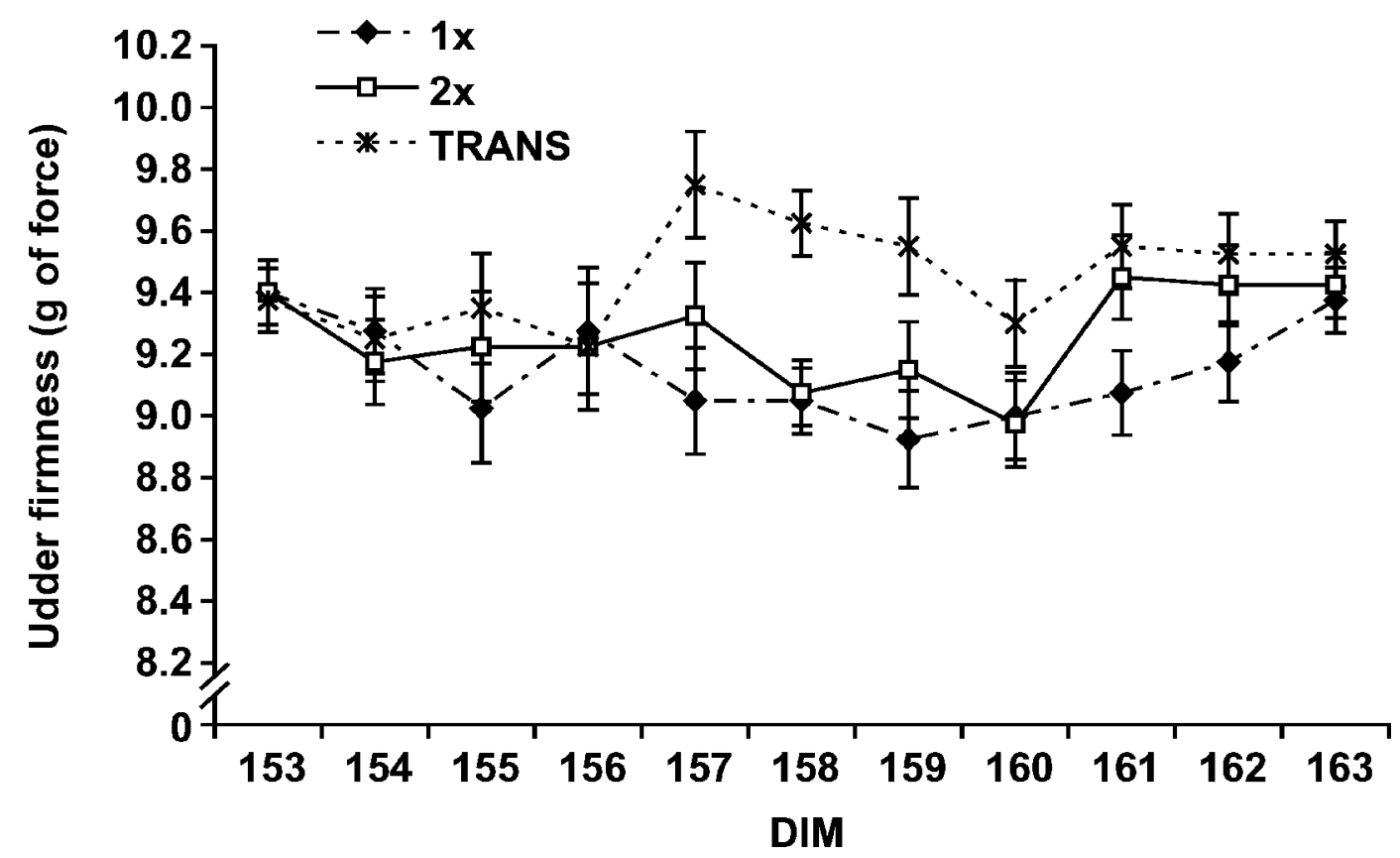

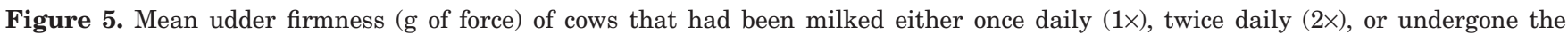
transition from $2 \times$ to $1 \times$ (TRANS) during mid lactation in a pastoral farming system in New Zealand. The TRANS group switched from $2 \times$ to $1 \times$ milking on the afternoon of DIM 156; thus, the first milking after the change was DIM 157. Bars represent SEM.

Redbo, 2001). Neither prediction was supported by our results. At peak lactation, cows milked $1 \times$ were more likely to lie with their hind legs touching their body. During the transition from $2 \times$ to $1 \times$ milking at mid lactation, when we expected to see discomfort associated with mammary gland distension; we found no differences in lying postures or the length of lying bouts.

We found evidence that udders became firmer (Figure 5) when milking frequency was reduced. Cows had firmer udders and were more likely to have milk leakage (Figure 4) upon entry into the parlor when milking frequency was reduced from $2 \times$ to $1 \times$. Previous work found that the reduction in milking frequency to $1 \times$ caused enough pressure in the mammary gland that the tight junctions become permeable and lactose leaked into the blood in the $24 \mathrm{~h}$ after this change (Stelwagen et al., 1997). In our experiment, changes in udder firmness and milk leakage associated with the transition to $1 \times$ milking were most marked on the day following the first missed afternoon milking and declined over the next $6 \mathrm{~d}$. Differences in udder firmness were not accompanied by increases in heat emitted from the udder, as might be expected if the changes in udder firmness were associated with inflammation (Berry et al., 2003). Instead, the temperature of the udder seemed influenced more by individual differences between cows than by milking frequency. The sampling method (every $24 \mathrm{~h}$ ), however, may have been insufficient to capture any changes in heat associated with a short-term inflammatory response.

Similarly, the likelihood of cows to step or kick in the parlor was not influenced by milking frequency. Cows were more likely to kick if they had teat lesions, a painful injury (Rousing et al., 2004). We predicted that cows milked $1 \times$ would be more likely to kick in the parlor because of discomfort with handling engorged udders. We found no difference in stepping or kicking behavior in the milking parlor associated with milking frequency, perhaps because there were no differences in udder traits (firmness or milk leakage) during peak lactation.

We predicted that cows with greater udder firmness or discomfort would have shorter strides when walking toward the milking parlor. Housed dairy cattle take shorter strides before being milked (Flower et al., 2006). Despite differences in udder firmness, there were no consistent differences in stride length to or from the parlor. Indeed, cows milked $1 \times$ had slightly longer strides than cows milked $2 \times$ at mid lactation. Cows with fewer hoof pathologies take longer strides than lame cows (Flower et al., 2005), and it is possible that milking only $1 \times$ reduced hoof wear and possibly incidence of lameness. Further research is required to assess the role of milking frequency in the development and incidence of lameness across farms. 
We found no differences in fecal glucocorticoid metabolite concentrations at mid lactation or during the transition from $2 \times$ to $1 \times$ milking. Previous studies reported higher plasma cortisol concentrations in cows milked $1 \times$ at peak lactation (until 21 DIM) compared with cows milked $2 \times$ (Keane et al., 2006), whereas others found no differences in plasma cortisol associated with milking $2 \times$ or $3 \times$ daily (Herskin et al., 2003). In our study and the work of others, the concentrations of plasma cortisol [mean of all treatment groups $<8 \mathrm{ng} / \mathrm{mL}$ in both Keane et al. (2006) and Herskin et al. (2003)] or fecal glucocorticoids (11 ng/g of feces) were within the range of basal values for dairy cattle. Milking cows $1 \times$ did not elicit a marked activation of the hypothalamic-pituitary-adrenal axis in our experimental conditions. As with our other response variables, further work is required to understand if these conclusions are relevant for higher producing cows, which may have more potential for discomfort due to udder distension. Indeed, the average milk production in our experiments, $27 \mathrm{~kg} / \mathrm{d}$ at peak lactation and $17 \mathrm{~kg} / \mathrm{d}$ at mid lactation, is likely lower than that in more intensive dairy systems. Similarly, the relatively small sample size in our experiments may have been insufficient to detect small differences in the dependent variables in a pasture-based system.

\section{CONCLUSIONS}

In the week following a reduction in milking frequency, $1 \times$ milking resulted in increased udder firmness. Despite these differences in udder firmness, the lying behavior and fecal glucocorticoid metabolite concentrations of cows milked $1 \times$ or $2 \times$ were similar. Although milking frequency did not influence time spent grazing, the diurnal grazing pattern of cows milked $2 \times$ was disrupted by afternoon milking. Cows were able to compensate for this by increased grazing activity upon return to the pasture. Cows milked $1 \times$ had longer strides than cows milked $2 \times$ in mid lactation. Further research is required to understand the benefits of reduced walking distances and handling associated with milking $1 \times$ for hoof health and lameness. In conclusion, we found no overt changes in behavior or physiology to indicate that the welfare of cows milked $1 \times$ was impaired.

\section{ACKNOWLEDGMENTS}

We gratefully acknowledge the technical assistance from AgResearch and Dexcel staff: Kate Brown, Katie Carnie, Gonzalo Carracelas, Adrienne Cook, Debbie Davison, Zoe Doidge, Suzanne Dowling, Sara Griffiths, Kirsty Hammond, Cara Hansen, Carley Hogan-Judd,
Paul Kendall, Estelle Liedemann, Tanya Little, Michelle Lo-Giacco, Steven Lo-Giacco, Anita Mans, Lynette Maulder, Mathias Muggeridge, Gavin Ng, Jacky Oldfield, Diane Penwarden, Kim Preston, Renee Railton, Chris Roach, Nina Ryan, Jacquie Rye, Holly Sarten, Rebecca Tonks, Nichole West, Zelda Wilson, and Sandra Zuger. We are grateful to the staff at Whareroa Research Centre, especially John Siemelink, to Christoph Winckler, at BOKU in Vienna, Austria for the use of the Gemini data loggers, and to Kerst Stelwagen for comments on a previous draft of this manuscript. This work would not have been possible without funding from Dairy InSight.

\section{REFERENCES}

Berry, R. J., A. D. Kennedy, S. L. Scott, B. L. Kyle, and A. L. Schaefer. 2003. Daily variation in the udder surface temperature of dairy cows measured by infrared thermography: Potential for mastitis detection. Can. J. Anim. Sci. 83:687-693.

Chesterton, R. N., D. U. Pfeiffer, R. S. Morris, and C. M. Tanner. 1989. Environmental and behavioural factors affecting the prevalence of foot lameness in New Zealand dairy herds - A casecontrol study. N.Z. Vet. J. 37:135-142.

Clark, D. A., C. V. C. Phyn, M. J. Tong, S. J. Collis, and D. E. Dalley. 2006. A systems comparison of once- versus twice-daily milking of pastured dairy cows. J. Dairy Sci. 89:1854-1862.

Davis, S. R., V. C. Farr, P. J. A. Copeman, V. R. Carruthers, C. H. Knight, and K. Stelwagen. 1998a. Partitioning of milk accumulation between cisternal and alveolar compartments of the bovine udder: Relationship to production loss during once daily milking. J. Dairy Res. 65:1-8.

Davis, S. R., V. C. Farr, and K. Stelwagen. 1998b. Once-daily milking of dairy cows: An appraisal. Proc. N.Z. Soc. Anim. Prod. 58:36-40.

Davis, S. R., V. C. Farr, and K. Stelwagen. 1999. Regulation of yield loss and milk composition during once-daily milking: A review. Livest. Prod. Sci. 59:77-94.

Flower, F. C., D. J. Sanderson, and D. M. Weary. 2005. Hoof pathologies influence kinematic measures of dairy cow gait. J. Dairy Sci. 88:3166-3173.

Flower, F. C., D. J. Sanderson, and D. M. Weary. 2006. Effects of milking on dairy cow gait. J. Dairy Sci. 89:2084-2089.

Herskin, M. S., L. Munksgaard, and A. M. Kristensen. 2003. Behavioural and adrenocortical responses of dairy cows toward novel food: Effects of food deprivation, milking frequency and energy density in the daily ration. Appl. Anim. Behav. Sci. 82:251-265.

Holmes, C. W., G. F. Wilson, D. D. S. Mackenzie, and J. Purchas. 1992. The effects of milking once daily throughout lactation on the performance of dairy cows grazing on pasture. Proc. N.Z. Soc. Anim. Prod. 52:13-16.

Keane, C. J., A. J. Hanlon, J. F. Roche, J. L. Burton, J. F. Mee, J. V. O'Doherty, and T. Sweeney. 2006. A potential antiapoptotic phenotype in neutrophils of cows milked once daily in early lactation. J. Dairy Sci. 89:1024-1027.

Ketelaar, D. L. C. C., A. H. Ipema, E. N. J. V. Ouwerkerk, M. M. W. B. Hendriks, J. H. M. Metz, J. P. T. M. Noordhuizen, and W. G. P. Schouten. 1999. Voluntary automatic milking in combination with grazing of dairy cows. Milking frequency and effects on behaviour. Appl. Anim. Behav. Sci. 64:91-109.

Lidfors, L., and P. Jensen. 1988. Behaviour of free-ranging beef cows and calves. Appl. Anim. Behav. Sci. 20:237.

Livestock Improvement Corp. 2004. Dairy Statistics 2003-2004. www.lic.co.nz Accessed on Jan. 26, 2005.

Morrow, C. J., E. S. Kolver, G. A. Verkerk, and L. R. Matthews. 2002. Fecal glucocorticoid metabolites as a measure of adrenal activity in dairy cattle. Gen. Comp. Endocrinol. 126:229-241. 
Österman, S., and I. Redbo. 2001. Effects of milking frequency on lying down and getting up behaviour in dairy cows. Appl. Anim. Behav. Sci. 70:167-176.

Pajor, E. A., J. Rushen, and A. M. B. de Passillé. 2003. Dairy cattle's choice of handling treatments in a Y-maze. Appl. Anim. Behav. Sci. 80:93-107.

Prescott, N. B., T. T. Mottram, and A. J. F. Webster. 1998. Relative motivations of dairy cows to be milked or fed in a Y-maze and an automatic milking system. Appl. Anim. Behav. Sci. 57:23-33.

Rauw, W. M., E. Kanis, E. N. Noordhuizen-Stassen, and F. J. Grommers. 1998. Undesirable side effects of selection for high production efficiency in farm animals: A review. Livest. Prod. Sci. $56: 15-33$.

Rousing, T., M. Bonde, J. H. Badsberg, and J. T. Sørensen. 2004. Stepping and kicking behaviour during milking in relation to response in human-animal interaction test and clinical health in loose housed dairy cows. Livest. Prod. Sci. 88:1-8.

SAS Institute. 1999. User's Guide: Statistics. Version 9.1 ed. SAS Institute, Inc., Cary, NC.

Stefanowska, J., M. Plavsic, A. H. Ipema, and M. M. W. B. Hendriks. 2000. The effect of omitted milking on the behaviour of cows in the context of cluster attachment failure during automatic milking. Appl. Anim. Behav. Sci. 67:277-291.

Stelwagen, K., V. C. Farr, H. A. McFadden, C. G. Prosser, and S. R. Davis. 1997. Time course of milk accumulation-induced opening of mammary tight junctions, and blood clearance of milk components. Am. J. Physiol. 273:R379-R386.

Tucker, C. B., G. A. Verkerk, B. H. Small, I. S. Tarbotton, and J. R. Webster. 2005. Animal welfare in large dairy herds: A survey of current practices. Proc. N.Z. Soc. Anim. Prod. 65:127-131. 